\section{PROPOSAL FOR A PAN-EUROPEAN PERSONAL PENSION PRODUCT (PEPP)}

Falco R. Valkenburg $A A G, R B A$,

(Independent consulting actuary based in The Netherlands, Member of the Board of the Actuarial Association of Europe)

\section{ÖSSZEFOGLALÓ}

Jelen cikk az Európai Bizottság jogszabálytervezetét, illetőleg annak hátterét mutatja be, mely egy EU-szintű európai nyugdíjtermék (PEPP) jogszabályi környezetének megalkotását célozza. Az írás elsősorban az induló javaslatot kívánja bemutatni, de szó lesz még a további menetrendről, illetőleg a jelen stádiumban még vitatott kérdésekről.

\section{SUMMARY}

This article describes the proposal for a Pan-European Personal Pension (PEPP) product by the European Commission. It provides the background for the proposal. The main part of the article is a summary of what is proposed for an EU-wide $2^{\text {nd }}$ regime for the PEPP. The article concludes with the process going forward and a brief mention of some topics of the current discussion.

Kulcsszavak: biztosítás, nyugdíjbiztosítás, PEPP

Key words: insurance, pension product, PEPP

JEL: E21, E22, G22

DOI: $10.18530 /$ BK.2018.3.6

http://dx.doi.org/1018530/BK.2018.3.6
The European Commission published on 29 June 2017 their proposal for a Regulation on a Pan-European Personal Pension (PEPP) product ${ }^{1}$. PEPP is basically a third pillar individual pension savings product. The European Commission mentions nine reasons for this proposal ${ }^{2}$.

The first four reasons are linked to the demographic challenges in Europe:

1. Ageing of the population

2. Ensure an adequate income in retirement

3. Current personal pension products are underdeveloped in some Member States

4. Need to complement the existing pension systems: state-based and occupational pensions

As many state pension arrangements are financed on the basis of pay-as-you-go, the ageing of the population creates a financial pressure to these arrangements. Less actives have to pay the retirement payments of the retirees. Such pension arrangements are now revised by lowering the payment in retirement, increasing the retirement age, other measures or a combination of measures. They all result in less adequate income in retirement. When there are no or limited possibilities for additional pension savings in order to 'compensate' the reduction of the state pension arrangements, there is a need to complement the current pension arrangements according to the European Commission

The next two reasons relate to the set up of a European Capital Market Union:

5. National markets in the European Union remain fragmented

6. Need to increase long-term investment in the European Union to foster growth and jobs

The final three reasons relate to an increase of cost efficiency:

7. Lack of competition

8. Insufficient supply of personal pension products in some Member States

9. Lack of transparency and ability to switch providers

The regulation proposes a voluntary, EU-wide $2^{\text {nd }}$ regime for a pan-European Personal Pension product. It is not about replacing any existing pension systems, including existing personal pension products. In addition, the European Commission published a recommendation to the Member States on the tax treatment of personal pension products, including the PEPP. This is remarkable as the field of tax is a matter for the sovereign states and is not territory for the European Commission.

\section{Many types of providers}

The proposal would make it possible for many types of providers to offer a PEPP product. Currently there is only one main type of personal pension provider: insurers. If already 
authorised under EU rules offering a PEPP product should be possible for asset managers, insurers, banks, IORP ${ }^{3}$ s and some investment firms.

\section{PEPP as a European label}

The European Insurance and Occupational Pensions Authority (EIOPA) will verify the compliance with the PEPP regulation. The objective is to create a European label for PEPP. This means that the authorisation to provide PEPPs and the designation 'PEPP' in relation to a personal pension product may only be used after authorisation by a single EU authority, which will be EIOPA. Of course EIOPA will then coordinate the work with other European Supervisory Authorities and National Competent Authorities.

\section{The objective is to create a European label for PEPP.}

Once a PEPP product is authorised, it can be distributed throughout the European Union and EIOPA will manage a central public register. A PEPP product will be supervised by National Competent Authorities. EIOPA will coordinate the supervisory workplans on an annual basis and will also get mediation power in case of cross-border disagreements.

\section{Distribution}

Distribution rules under the Insurance Distribution Directive (IDD) and Markets in Financial Instruments Directive (MiFID II) apply to insurers and investment firms and specific rules apply to other providers. Documents must be provided electronically. A PEPP key information document in line with KID under PRIIPs Regulation should be provided, with additional information including information on switching, portability and ESG $^{4}$ policy. PEPP savers may waive the right to advice if they select the default investment option. PEPP providers must draw up a personalised PEPP Benefit Statement similar to the Pension Benefit Statement under the IORP II Directive. The Commission will adopt delegated acts regarding the determination of assumptions for the projections. EIOPA will develop Implementing Technical Standards (ITS) on the PEPP Benefit Statement.

\section{Investment options}

The prudent person rule applies to the investment of contributions to a PEPP. The proposal states further that a PEPP provider:

- $\quad$ shall offer up to five investment options to PEPP savers (meaning 'no more than five')

- $\quad$ shall include a default investment option and may include alternative investment options ['at least one of them shall offer a cost-effective investment option to PEPP savers']
- $\quad$ shall ensure sufficient protection for PEPP savers by designing all investment options on the basis of proven risk-mitigation techniques

The PEPP saver selects an investment option at inception and may change this once every five years without charge. The default investment option shall ensure capital protection for the PEPP saver. This means that the PEPP saver must be able to recoup the capital invested. The European Commission may adopt a delegated act specifying the risk-mitigation techniques.

\section{Switching providers}

PEPP savers may switch providers - within a Member State or cross border - "no more frequently than once every 5 years after conclusion of the PEPP contract". Information on current balances etc. must be provided free. The total fees and charges applied by the transferring PEPP provider for closing the account must not exceed $1.5 \%$ of the balance transferred. The PEPP saver shall bear the costs and any loss incurred in redeeming the assets for the sake of transfer. "The PEPP saver shall bear the costs and any risk of financial loss connected with the capital protection provided by the transferring PEPP provider. This capital protection ...shall be consumed at the moment of switching providers.". Any other charges imposed by the transferring or receiving PEPP provider must be reasonable and in line with actual costs.

\section{Decumulation}

The Member State determines the conditions relating to decumulation options. This includes setting the retirement age, minimum and maximum saving periods, redemption in case of particular hardship. PEPP providers may make available to PEPP savers one or more of the following forms of out-payments:

- annuities;

- lump sum;

- drawdown payments;

- combinations of the above forms.

The choice of decumulation approach is made by the PEPP saver at the outset and can be changed once every five years during the accumulation phase thereafter. The list of decumulation options in the proposal covers all the possible options under the proposal, but keep in mind that the decumulation options are restricted to what the Member State allows them to be. This might mean that in a given Member State only one particular option is allowed.

\section{Feasibility Study}

On the request of the European Commission, Ernst \& Young (EY) has undertaken a feasibility study. This study includes a tax mapping. Most Member States apply the EET tax 
construction. This means the contributions to the product are exempt (E) of (income) tax, Investments returns in the accrual period are likewise exempt $(\mathrm{E})$ and the payments in the decumulation phase are taxed $(\mathrm{T})$. The study further points at stark differences between Member States in levels of market penetration. EY advises that the default investment option should not be defined at EU level. EY don't think a capital guarantee is needed.

\section{Ernst \& Young advises that the default investment option should not be defined at EU level.}

Harmonisation of the decumulation phase does not need to be a requirement. EY suggests that the provision of PEPPs should be open to asset managers and banks, as well as insurers. EY estimates the market potential to be $€ 0.7$ trillion by 2030 .

\section{Process}

The process is now that both European Parliament and the European Council of Ministers will develop a response. Such responses usually include many suggestions for amendments. These three documents (Commission proposal, response Parliament and response Council) will then form the basis for the discussions amongst the three European legislative bodies. This is referred to as the Triologue. The current expectation is that both Parliament and Council will finalise their responses mid 2018. The Triologue could then take place in the second half of the year. The aim is then to conclude the Triologue before the end of the year and at least before next year's European elections.

\section{Discussions and amendments}

From the discussions in Parliament and the papers produced by the rapporteur of the European Parliament, Sophie in 't Veld MEP (Netherlands), it appears that there is a good deal of support in general for the PEPP proposal. At the same time, it is also clear that Parliament will propose many amendments to the original proposal. This is very common though. It is likely that also the Council will have many wishes to amend the proposal as well. Topics for discussion are: whether the default should have a guarantee, which providers are allowed to provide a PEPP, how to incentivise a PEPP product via tax or otherwise, how to achieve transparency in costs and many more. There is also debate about the differences between providers in terms of capital requirements. These differences result in fact in different PEPPs even if all specifications are further the same. Generally spoken one could say that a product offered by an insurer will offer a higher level of certainty than a product offered by a pension fund that has lower capital requirement than would be the case under Solvency II.

\section{Sources}

The proposal of the European Commission for a regulation on a pan-European personal pension product (PEPP)

https://ec.europa.eu/info/publications/170629-personal-pension-products_en

Presentation of 5 October 2017 from the European Commission to EIOPA's Occupational Pensions Stakeholder Group

https://eiopa.europa.eu/Publications/Meetings/04._COM_Presentation_PEPP_Proposal_\%28COM\%29.pdf 